\title{
INNOVATION OF THE ECONOMY AS A KEY DETERMINANT OF ECONOMIC DEVELOPMENT
}

\author{
Adrijana Vuković ${ }^{1}$ \\ Marijana Milunović2 \\ Krsto Jakšić ${ }^{3}$
}

DOI: https://doi.org/10.31410/ERAZ.2019.129

\begin{abstract}
The contemporary world is painted with constant changes, in which the key to economic success lies in the ability to understand them and to optimally adapt to the new business environment. Under conditions where changes are gaining more and more intensity, the condition for the development of every economy becomes precisely innovation.

Innovation is a significant factor in the development of the economy and society. As a fundamental driver of the growth of the modern economy, innovation is closely related to the development of science and the creation of new knowledge that is being developed, materialized and applied through innovations through the innovation process. The development of the economy is precisely determined by the ability to create, transfer, apply, and commercialize new knowledge through innovation.

The subject of this paper is innovative economies that adapt faster and more successfully to changes in a dynamic environment, more effectively solve social challenges, change the economic structure faster and more successfully and create a viable competitive advantage. The aim of this paper is to point out that the improvement of innovation is a key factor in building an economy and a knowledge-based society, whether it's developed or developing countries.
\end{abstract}

Keywords: innovation, economic growth and development, strategy, change, knowledge.

\section{INTRODUCTION}

$\mathrm{T}$ ransformation of economies of the world into global economy is becoming increasingly more intensive and it brings a qualitative change in economic relations and global economic trends. The global economic system and the creation of a dynamic and flexible global economic order are the products of intensive process of today's changes.

Events in global economy take place with great speed. Map of the world has changed drastically in economic sense, and global business conditions impose constant challenges for improvement.

One of the main characteristics of modern economic trends is the increasingly greater connection and interdependence. Economic development itself is a complex process in its nature, and explanation of this process cannot rely only on traditional economic factors, but strong effects coming from educational, institutional and technological field must be taken into consideration. Knowledge represents a powerful and increasingly more used base for explanation of collective and individual activity, which contributes to success of development of the economy itself.

$1 \quad$ Union - Nikola Tesla University Belgrade, Faculty of Law, Security and Management "Konstantin Veliki", Niš, Sebia

2 Union - Nikola Tesla University Belgrade, Faculty of Management, Sremski Karlovci, Serbia

3 University of Priština temporarily settled in Kosovska Mitrovica, Faculty of Economics, Kosovska Mitrovica Filipa Višnjića bb, Serbia 
World economy may be observed as a type of pyramid - a hierarchy of knowledge, where those who keep investing in knowledge remain on top. Creation and successful application of new know-how through innovations is a fundamental source of growth of productivity, competitiveness, opening of new work places and economic growth. Without innovative activity, in modern conditions, it is impossible to envision success of economy as a whole. Considering the relevance that innovation has for economic development, each country tries to perfect its business environment to the greatest extent possible, so as to enable it to become favourable for continuous development of innovations. Observing of innovative results is of great relevance, because these results represent a base for defining the developmental policy of each country, and they are an important base for its implementation. [1]

\section{MODERN TENDENCIES IN ECONOMY}

The modern world is painted by constant changes, where the key to economic success lies in the ability to understand them and in the optimal adjustment to the newly established business environment. These changes have significantly changed the image of the modern world, region, state and enterprise. Changes that take place are not tied to any specific place on the planet, but they do affect each place individually. [2]

The world has gone through many economic paradigms and it is already faced with common responsibility and necessity to harmonize its economic development with the needs of people and of the nature.

The essence and purpose of economic development of the society is reflected in the continuous improvement of various subsystems of the society - economy, politics, culture, etc. One of the key requirements for economic development, and for growth of social well-being, is the development and improvement of production structures, with participation of high-tech branches, science and education in the capacity of key growth factors [3]. This achieves a synthesis of structural, technical and technological and institutional changes, which leads to increase of economic success and competitiveness. The process of adoption and implementation of the most advanced industrial technologies, economic forms, and their corresponding social and political institutions, have a decisive influence on the achievement of goals and priorities of economic growth and development.

The matter of development of the economy today has greatly evolved and it overcame theoretical considerations that applied before. Economic, social, technical and technological changes are focused on the launching of economic growth and on sustainability of development, in order to overcome economic backwardness. The process of transformation of the manner of behaviour of economic subjects is focused towards qualitative progressive changes of existing institutional forms, technological improvement of economic system and strengthening of its competitiveness.

Thanks to application of modern technologies, an impulse for change of tradition and social values is being created. [4] Former development, which is based on natural limitations in achievement of high growth rates over a long period of time, is being shaped into the developmental concept that applies today. This concept is based on a new growth theory which focuses on applied knowledge and complex of scientific and technological development. Former understanding of wealth was measured with physical and financial capital, but today, a key determinant of national wealth is the ability to develop new knowledge, ideas, innovations and technologies, i.e. to create human capital and disposing of it. (National Strategy for Sustainable Development) 
These new waves change the society, not only in the sphere we refer to as economy, but far beyond it. Development of IT and communication technologies, manufacture and use of new materials, has created unimagined possibilities for networking and connecting of commodity, and particularly financial flows, which were unimaginable until recently. Instead of natural resources, fertile soil, mineral resources and available capital, the applied knowledge, education and science have become dominant factors for development of modern economy in almost entire world.

\section{THE POWER OF THE ECONOMY OF KNOWLEDGE}

We are witnessing the fact that the time we live in is characterized by continuous and dynamic changes. However, each change doesn't produce a positive effect, which is especially inherent to changes in modern conditions, which are mainly devastating, destructive, negative, and often undesirable. Positive changes based on the process of application of new ideas in order to achieve better results, whether within a company or on the level of economy as a whole, have a direct impact on economic development of the entire society.

In parallel with the acceleration of development in the world, a global environment is created. In an economy characterized by globalization, fast technological changes, changes in consumers' preferences, dominance of knowledge and need for quality information, entire regions are connected in order to acquire the strongest position possible on the global economic and financial stage. Those who don't take part in these processes will quite certainly remain marginalized on the long run, excluded from main flows of information and knowledge, and as the time passes it is increasingly more difficult to compensate for the missed opportunities.

In conditions when the changes are becoming more intense, the key factor for competitiveness of every economy is precisely innovation. The real economic drivers are new knowledge and new achievements, i.e. when new knowledge finds its way to the market. Economy guided by innovation will gain a competitive position on the global market through constant innovations. Introduction and diffusion of an innovation is conducted with the goal to create economic value.

Knowledge represents the most important factor for development of economy. Today, "knowledge-based economy", i.e. "economy of knowledge" has become recognizable and very popular. We might say that there are hardly any economically developed countries of the world without a separate policy or strategy for inciting knowledge-based economy. (National Strategy for Sustainable Development)

Modern economy depends increasingly more on knowledge, information and specific skills, which affects the increase in a share of knowledge-based high-tech production. In such conditions, success depends on organizational, economic, social and other knowhow. The innovation process starts with the discovery of knowledge about the fact that there are gaps in knowledge which can be used as a new, potential market need. Activities based on new knowledge stimulate the appearance of new types of innovation and allow the innovation process to adjust itself to requirements for development of a society based on knowledge.

Economic policy that is supposed to incite the climate of innovations through certain measures has great influence on development. Each economy has its characteristics, which determine innovative abilities to a greater or smaller extent. [5] Certain macroeconomic performances of 
a country explain the difference in the quality of certain components of the innovative capacity of the economy.

Each country tries to improve its business environment to the greatest extent possible, to make it favourable for continuous development. This is not a big problem for developed countries in comparison to underdeveloped countries that don't have sufficiently developed scientific and technological capacity that would incite the creation of necessary knowledge about innovations.

It is more difficult to keep up with more advanced market economies today than it was in the past. Success on the long run requires thinking on the long run - a vision. A country's task is to continuously search for actions necessary to launch and maintain the momentum of the economy.

For a more successful functioning of the economy, which would achieve a more dynamic economic growth and sustainability of development, it is necessary to create economic system and economic policy that will allow for achievement of priority goals in a satisfactory manner.

\section{INNOVATIONS AS FUTURE CONCEPT OF ECONOMIC DEVELOPMENT}

Innovations represent the key driver of economic growth. Fast technological changes in previous years created great opportunities, as well as challenges. Innovation comes in different sizes and shapes. From time to time, great waves of innovation fall upon the society and thus create discontinuity and penetration in the development of knowledge.

Innovations are an important factor for the increase of each country's competitiveness. Sadly, in some countries, the innovative climate has not yet been accepted, which represents a great challenge for these countries when it comes to innovation. There isn't a business environment that would incite the development of innovations in the appropriate manner. It is necessary to create a business environment where intellectual property would allow the innovators to draw economic value from their work and increase economic success and competitiveness.

Low allocations for science, insufficient cooperation between science and economy in terms of commercialization of research and innovative projects, lack of institutional framework for support to innovations, uncertainty of financing of scientific and research organizations, lack of researchers, i.e. "brain drain", are merely some of the factors that significantly hinder the innovative ability in many countries, among which we should mention Serbia, as well as other countries in its region.

From the aspect of innovations, a lot needs to be done in less developed economies on improvement of internal structures of knowledge, technology and other material and non-material assets, i.e. on improvement of own innovative capacity. Only after an appropriate knowledge base is established and after innovative possibilities are observed, we can work intensively on the connecting with external sources of knowledge and technologies and to create new values through productive and effective combination of internal and external sources and thus improve the national investment culture. [6]

In comparison to developed countries in the world, the innovation potential of Serbia, and of countries in the region, is in a far worse position. Such position, among other, stems from the fact that there is no adequate access to sources of financing, investments in research and development 
of new products and services, and market development. The rate of investments in research and development, and in education, is very low, and insufficient for the needs of the country.

Compared to developed European countries, the innovation potential in Serbia's private sector is in a worse position in terms of access to market, sources of financing and investments in research and development of new products. It is estimated that total investments in science in Serbia don't go over $0.5 \%$ of GDP, according to which Serbia is still classified among the countries with the lowest investments in science, both in the developed world and in the region. A very low share of research and development costs in GDP in Serbia testifies this (Ristić et al. 2016, p.23). National system of innovations is a network of public and private institutions whose activities and interactions determine the creation, import, continuous improvement and the widest diffusion of new technologies. [7]

According to the Global Innovation Index 2018 Report, Switzerland is at the top of the table of most innovative economies that were selected based on availability of information about certain determinants that are relevant for innovation of the economy. EU countries are also leading countries when it comes to innovation index.

Table 1: Top 10 most innovative economies in the world in 2018, according to WIPO [8]

\begin{tabular}{|l|c|c|}
\hline Country & $\begin{array}{c}\text { Value of Global } \\
\text { Innovation Index }\end{array}$ & Position \\
\hline Switzerland & 68.4 & 1 \\
\hline The Netherlands & 63.32 & 3 \\
\hline Sweden & 63.08 & 4 \\
\hline Great Britain & 60.13 & 5 \\
\hline Singapore & 59.83 & 6 \\
\hline USA & 59.81 & 7 \\
\hline Finland & 59.63 & 8 \\
\hline Denmark & 58.39 & 9 \\
\hline Germany & 58.03 & 10 \\
\hline Ireland & 57.19 & \\
\hline
\end{tabular}

Serbian economy, as well as the economies of other countries in the region, has a low level of innovation, which can be seen in Table 2. Serbia cannot boast with its position on the innovation list. It is ranked $55^{\text {th }}$. We may conclude that according to innovation performances, Serbia is significantly lagging behind compared to average and most countries of Europe.

Table 2: Global Innovation Index for countries of the region, 2018, according to WIPO [9]

\begin{tabular}{|l|c|c|}
\hline Country & $\begin{array}{c}\text { Value of Global } \\
\text { Innovation Index }\end{array}$ & Position \\
\hline Croatia & 40.73 & 41 \\
\hline Montenegro & 36.49 & 52 \\
\hline Serbia & 35.46 & 55 \\
\hline Bosnia Herzegovina & 31.09 & 77 \\
\hline
\end{tabular}

The fundamental problem that impedes the development of innovation in these countries is that the excellence of scientific research and their relevance for economic and social development of the country and society in whole are not sufficiently supported by the research financing system. The system for management of scientific and innovation system is not sufficiently effective, and coordination of work of relevant institutions and various stakeholders is very weak. What is characteristic for Serbia, as well as other countries in the region, is the lack of appropriate 
human resources in scientific and research organizations, economy, public sector, and the lack of long-term measures for resolving the given issue.

One of the conditions necessary for development of innovative potential is the creation of a business environment that would be favourable for encouraging an innovative climate, i.e. business environment that would enable economic success and increase these countries' competitiveness in the world. [10]

\section{CONCLUSION}

Business operations in modern conditions require an innovative manner of thinking, acting, doing business and functioning. Innovation is the main driver and carrier of development of modern economy. Since everything today is observed on a global level, innovation is also observed globally. Innovation in the entire process of economic activities is getting a key role. This role is seen in the specific meaning and power given to innovation and its real representation of the possibilities that a country has at its disposal.

The most important task for every economy that wants to move forward is how to achieve economic growth and development. This requires constant improvement, innovation and achievement of significant results. Economic development achieved through application of innovations becomes a factor that has a strong influence on a country's power.

Development of innovations is the safest way to increase productivity and resolve problems with development. Innovative economies adapt to changes faster and more successful in a dynamic environment, often dictating the direction, scope and dynamics of changes. At the same time, economies with a low level of innovative development are left behind, because innovation is one of the main pillars for development of the economy.

\section{REFERENCES}

[1] Dajić, M. (2017), Uloga i značaj inovacija u razvoju privrede Srbije, Ekonomski signali, Leposavić, pp. 55-64

[2] Vuković, A., Đoković, G., Čelik, P., (2013) Position of entrepreneurship in Serbia influenced by transition process and macroeconomic trends, Ekonomika, Niš, pp. 38-42

[3] Jasin, E. (2011), Institucianal'nye ograničenija modernizacii ili Priživetsja li demokratija v Rossii, Voprosy Èkonomiki, 11, pp 4-24

[4] Haviland, W. A. (2002), Cultural anthropology, 10th edition, Wadsworth/Thompson Learning, USA, pp. 137

[5] Ristić, N., Vukajlović, V., Brazaković, P. (2016), Inovacije kao pokretački faktor razvoja privrede, Ekonomija teorija i praksa, godina IX, broj 1, Novi Sad, pp. 19-34

[6] Cvijić, M., Borocki, J., Lalić, D. (2012), Otvoreni modeli inovacija, Zbornik radova: Inovacije i preduzetništvo - otvoreni modeli za uspeh na tržištu EU, Fakultet za ekonomiju, finansije i adminstraciju, Beograd, pp. 33

[7] Freeman, C. (1987), Technology Policy and Economic Performance, Frances Pinter, London, pp. 119

[8] https://www.wipo.int/pressroom/en/articles/2018/article_0005.html

[9] https://www.wipo.int/edocs/pubdocs/en/wipo_pub_gii_2018.pdf

[10] https://www.weforum.org/ 